\title{
Estimation of Natural Groundwater Recharge in Qatar Using GIS
}

\author{
$\underline{\text { Husam Baalousha }}^{\text {a }}$ \\ ${ }^{a}$ Qatar Environment \& Energy Research Institute (QEERI), Tel: +974 44547367, \\ PO Box: 5825 Doha Qatar \\ Email: Baalousha@web.de
}

\begin{abstract}
Qatar is an arid country with limited water resources. With no surface water and an average annual rainfall of $80 \mathrm{~mm}$ per year, Qatar relies on desalination to meet the increasing water demand. As a result of groundwater overexploitation, the water table has dramatically dropped to unprecedented levels and salinity increased, in addition to other adverse environmental impacts.

In the light of Qatar's 2030 National Vision, three grand challenges facing the future of Qatar were identified. One of three main grand challenges is the artificial recharge of groundwater. To understand the water budget and to better manage the precious groundwater resources, it is important to estimate the natural groundwater recharge and its mechanism.

This study is based on historical groundwater level data in combination with topography data and hydraulic parameters to estimate the amount and spatial distribution of natural groundwater recharge. With the help of Geographical Information System (GIS), maps of topography and contour maps of groundwater level and rainfall were prepared. Watershed modelling was done to identify areas of surface water accumulation were recharge is likely to occur. A good match was found between watershed modelling results and historical groundwater data.

Results show groundwater recharge occurs in three areas: two in the northern part of the country and two in the south. In general, the majority of recharge area occurs in the northern part of the country.
\end{abstract}

Keywords: Groundwater, GIS, recharge estimation 


\section{INTRODUCTION}

Qatar is an arid country located in the eastern part of the Arabian Peninsula. It is a small peninsula with a maximum length of $180 \mathrm{~km}$ in the north-south direction and a maximum width of $65 \mathrm{~km}$; thus the total area of Qatar is $11,586 \mathrm{~km}^{2}$. The country is surrounded by the Arabian Gulf from East, North and West, and bounded by Saudi Arabia in the South (Figure 1).

As a result of rapid economic expansion, the population of Qatar has dramatically increased from 600,000 in 2000 to 2,200,000 in 2014 (World Bank Data, 2014). With little rain and little groundwater resources, Qatar is relying on desalination of seawater to meet the increasing demand of its rapidly increasing population. The produced and stored desalinated water at any time meets the population needs for a few days only, and thus it is considered as one of the national security grand challenge to diverse water resources, including artificial groundwater recharge.

The groundwater aquifers have been overexploited over the last three decades, resulting in a great drop in groundwater levels and deterioration of water quality. The abstracted groundwater is mainly used for irrigation, which is concentrated in farms in the northern and central parts of the country.

As the country is fully relying on desalination plants to meet its need of water supply, the country is looking into other sources. Hence, Aquifer storage and recovery was identified as one of the main countries grand challenges. The successful criteria for such a recharge scheme are to maximize the recovery rate and to maintain a good quality of the recharged water.

A groundwater model is being built for the aquifers in the country, which will be used to understand groundwater flow regime and to examine different scenarios for groundwater recharge. Natural recharge from rainfall is one of the main input parameters for the groundwater flow model. In addition to natural groundwater recharge, other components such as leakage from water system network and irrigation return flow contribute to recharge. This paper presents a methodology to estimate rainfall recharge based on topography and GIS contours of piezometric surveys of groundwater.

Some studies have been done to estimate groundwater recharge from rainfall. Yurtsever and Payne (1978) used isotopes data to estimate groundwater recharge in the northern part of the country. Their recharge estimation results show a variation between 7 and 24 million $\mathrm{m}^{3}$ per year. Eccleston et al (1981) estimated recharge at $12 \%$ of rainfall in the north and $6 \%$ in the south. Vecchioli (1976) indicated that rainfall recharge is 20.9 million $\mathrm{m}^{3} /$ year, whereas another study (Kimrey, 1985) suggested 27 million $\mathrm{m}^{3} /$ year. A recent study by FAO (2014) estimated rainfall recharge at 65 million $\mathrm{m}^{3} /$ year.

This study uses topography features and groundwater contour maps to estimate the natural groundwater recharge in Qatar. Using Spatial Analyst in ArcGIS, and Digital Elevation Model (DEM), recharge zones have been delineated and the spatial distribution of the estimated recharge has been identified.

\section{HYDROGEOLOGY}

Qatar peninsula is part of the Arabian Shelf, which covers the eastern part of the Arabian Peninsula. It is underlain by a series of little dipping and flat lying deposits over the rocks basement. The surface of Qatar is of low relief with the highest altitudes of about $107 \mathrm{~m}$ occurring in southern Qatar, where large sand dunes and limestone anticline exist. Groundwater recharge from rainfall is quite variable due to erratic nature of rainfall event in desert climate. Most recharge occurs in land depressions, which resulted from collapse of karst features. After heavy storms, surface runoff accumulates in these depressions and recharges the aquifer (Figure 2).

Several anticlines rose above the main geological platforms in the Arabian Shelf, and extending in the north south direction. There are two major anticlines in Qatar; the Dukhan anticline in the west and Qatar anticline (Qatar Arch) in the middle of the country.

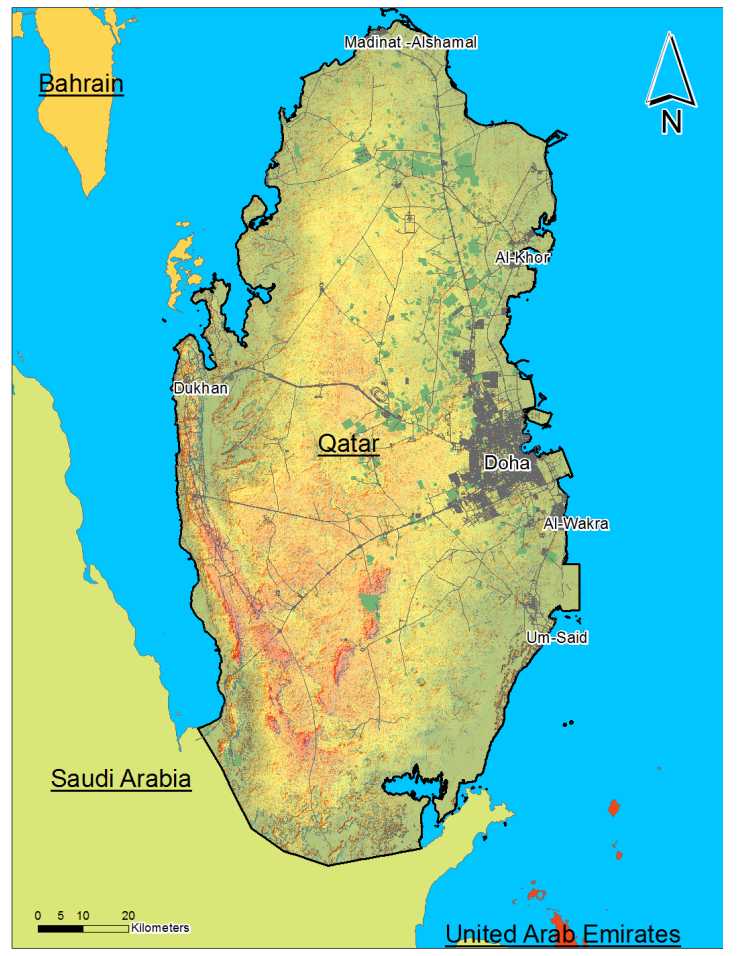

Figure 1. Location map of Qatar. 
The main geology in Qatar comprises formations from Neogene and Paleogene periods, overlain by Quaternary deposits (Boukhary et al 2011, Al-Yousef, 2003, Alsharhan et al 2001). The most recent deposits are the Dam Formation which covers most of the country except for small areas in the north, where older Rus Formation is exposed. Dam Groundwater in Qatar occurs either in Dammam Formation or in the underlying Rus Formation. Aquifers are categorized into three basins; the northern, central and southern basins. The northern is the main one, with least salinity. Groundwater occurs in form of fresh lenses situated atop of more brackish and saline groundwater. Most abstraction wells exist in this basin. The central basin is more saline than the northern but still usable for agriculture. The southern basin is the smallest and contains poor-quality water.

\section{TOPOGRAPHY AND RAINFALL CATCHMENTS}

Groundwater recharge occurs on the top Dammam aquifer. The northern part of the country receives higher recharge due to higher rainfall. Many depressions occur in the kart geology in Qatar, as shown in Figure 2. The land depressions occur all over the country and vary in depth and size from a few meters to more than a kilometer wide (Eccleston et al 1981). In the north, the depression occurred as a result of dissolution of limestone as rainfall infiltrates the limestone. As these fractures widen over thousands of year, collapse occur. The mechanism by which these depressions occur in the south is different due to the presence of sub surface strata of anhydrite. As rainfall infiltrates in the south, dissolution of the anhydrite strata causes cavitation underground. As a result of increasing the size of these cavities the land surface collapsed causing big depressions. These karst depressions are where then rainfall accumulates and infiltrate into the aquifer.

Average annual rainfall in Qatar amounts to $80 \mathrm{~mm}$ and the spatial distribution increases from south to north. The rainfall accumulation and topography were used to delineate surface water catchments as shown in Figure 3.

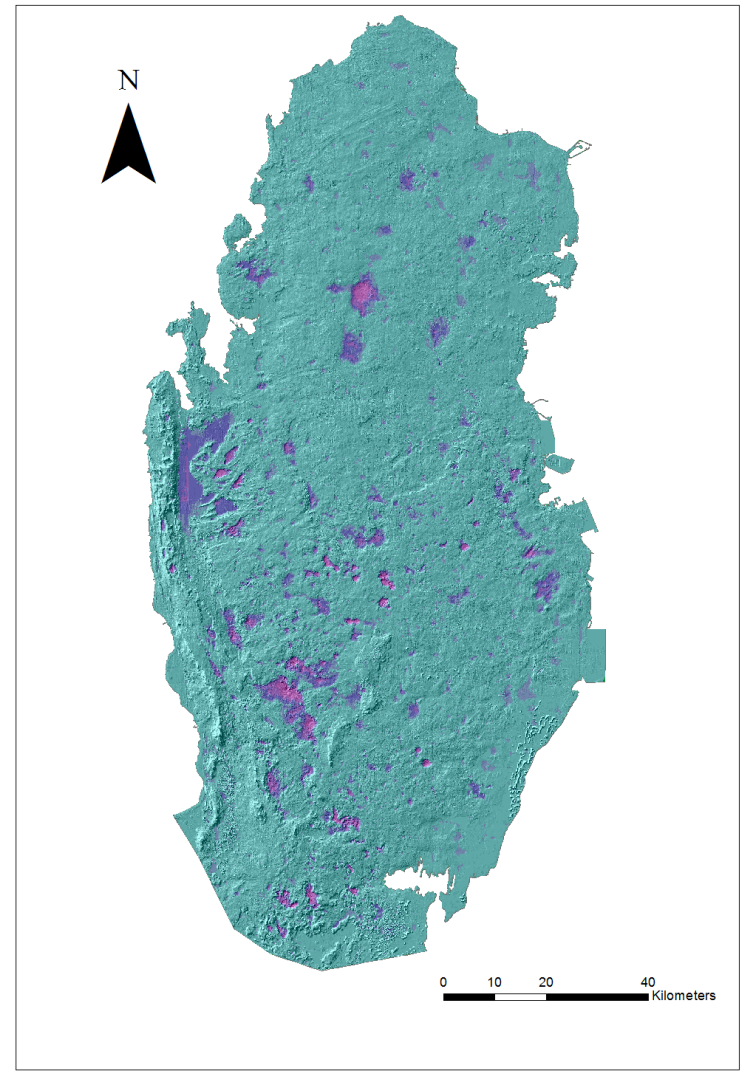

Figure 2. Hill-Shade model and land depressions.

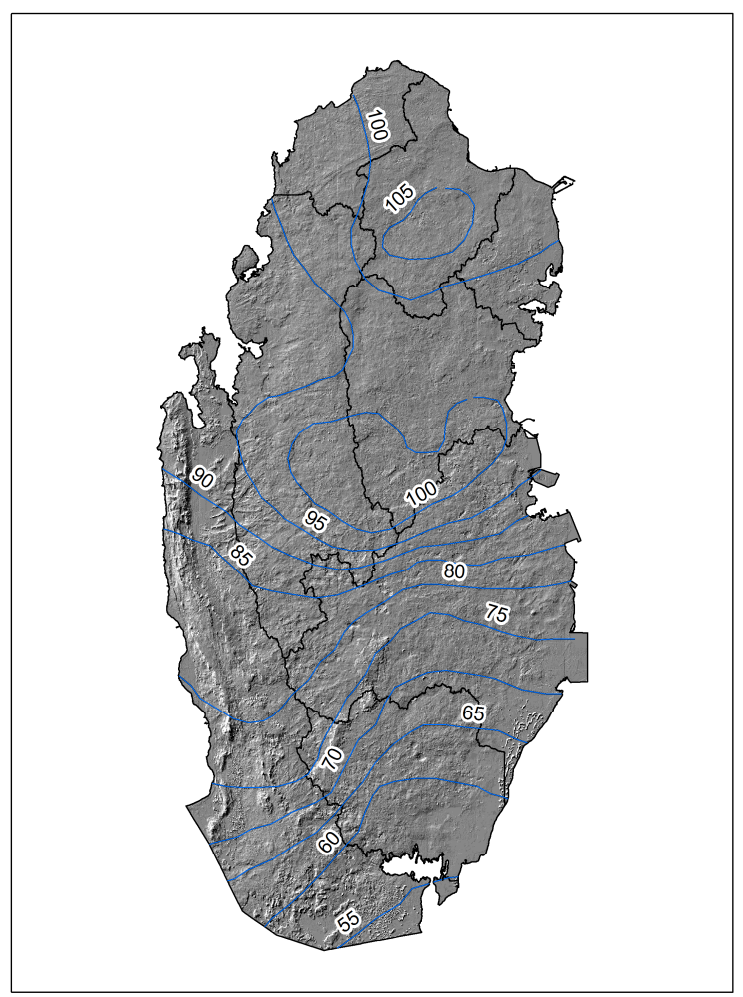

Figure 3. Rainfall distribution and surface catchments. 


\section{GROUNDWATER CONTOURS}

Historical groundwater levels contour maps are available and covering the main aquifers in Qatar. The oldest map is from 1958, as is shown in Figure 4. It is noted that groundwater level varies between 13 meters above mean sea level to 0 close to shoreline. It is also noted that the groundwater level follows the topography and

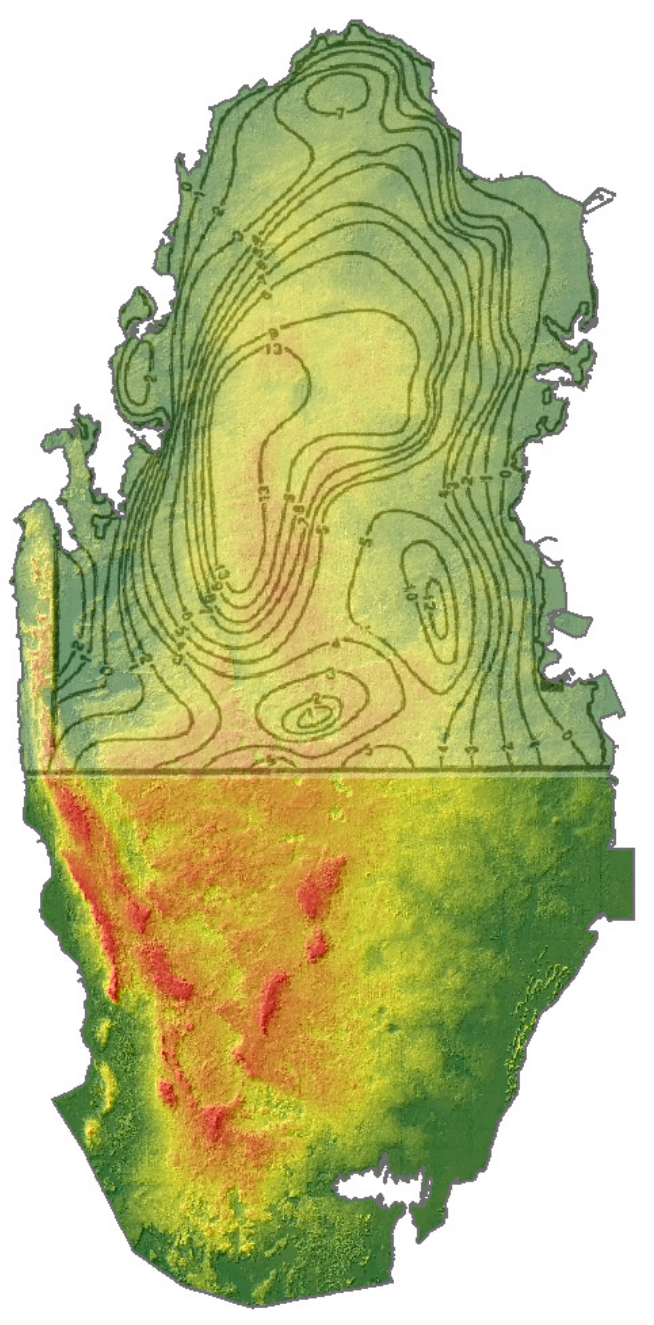

Figure 4. Groundwater level contour map in 1958.

flows from the high to low terrain, as is shown in Figure 4. Similar behavior can be seen in the other piezometric map, as is shown in Figures 5 and 6. In all cases, it is noted the groundwater flows from the middle of the peninsula towards the coast and the peak groundwater head is consistent with land depressions, where the groundwater recharge takes place. 


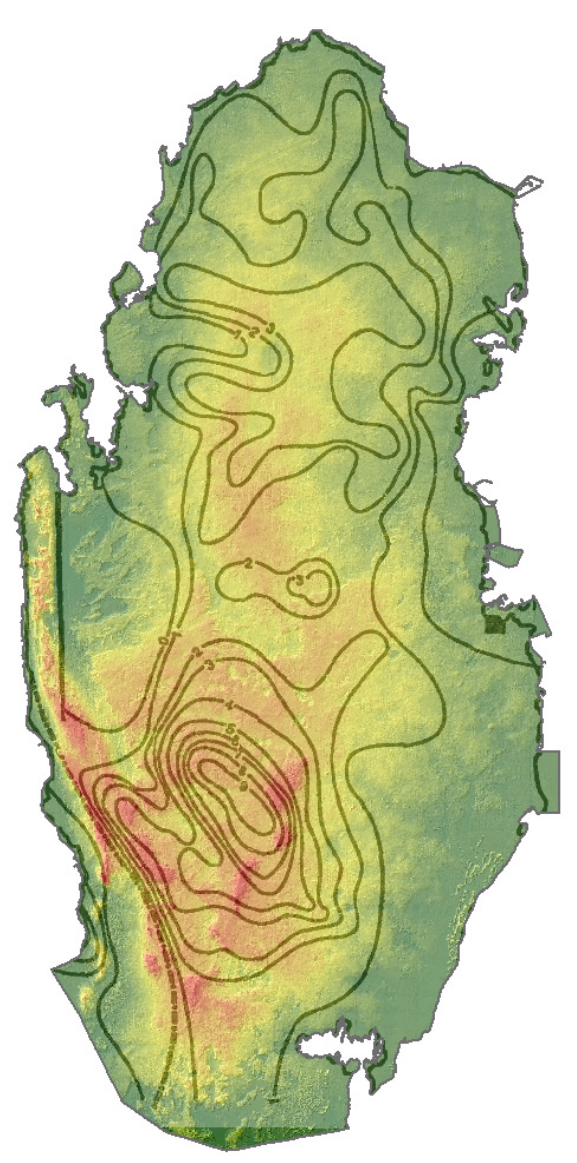

Figure 5. Groundwater level contours in 1985.

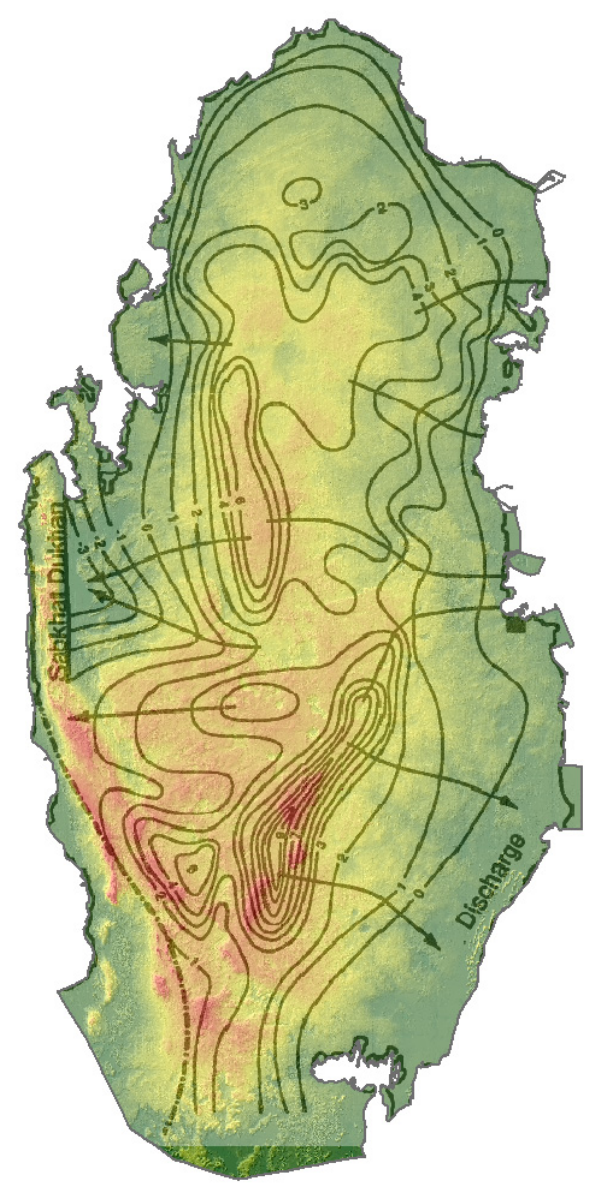

Figure 6. Groundwater level contours in 1980.

\section{Recharge Estimation}

Analysis of groundwater level contour maps for the period between 1958 (the oldest available map) and late 1990 's enable understanding the flow regime and identification of recharge/discharge zones. Based on this analysis, six areas of groundwater recharge were identified, as shown in Figure 6. These areas are consistent with land surface depressions and peaks of contours, as shown in Figures 4-6. It should be noted that the shape and location of these recharge areas, as appear in Figure 6, might slightly vary from time to time due to variation in rainfall. With the help of ArcGIS, average lengths of peak contours were measured and the groundwater flow from contours peak was estimated using Darcy's Law:

$$
R=T \frac{d h}{d x} \text { Equation (1) }
$$

Where $\mathrm{T}$ is the transmissivity $\left[\mathrm{L}^{2} / \mathrm{T}\right]$, which is derived from pumping test data (Schlumberger Water Services, 2009). The head gradient was estimated from the distance between contours.

From aquifer test results it is found the transmissivity is higher in the north than the south. Table 1 below lists the peak contour perimeters and the corresponding transmissivity. Using Equation 1, the groundwater recharge was calculated assuming over an average hydrological year. 
Table 1. Calculation of groundwater recharge.

\begin{tabular}{|c|c|c|c|c|}
\hline Perimeter (Km) & Area & $\begin{array}{c}\text { Transmissivity } \\
\left(\mathbf{m}^{\mathbf{2}} \mathbf{d}\right)\end{array}$ & Head gradient & $\begin{array}{c}\text { Total flow (over a } \\
\text { year) million } \mathbf{~ m}^{\mathbf{3}}\end{array}$ \\
\hline 156 & North & 203 & 0.00058 & 18.37 \\
\hline 54 & North & 149 & 0.00035 & 2.82 \\
\hline 26 & North & 390 & 0.00032 & 0.18 \\
\hline 42 & South & 10 & 0.00042 & 0.68 \\
\hline 114 & South & 5 & 0.0012 & 0.13 \\
\hline 38 & South & 10 & 0.00033 & \\
\hline
\end{tabular}

From Table 1, it is found that the average groundwater recharge from rainfall amounts to 25.4 million $\mathrm{m}^{3}$ per year. It is noted that the southern part of the country received little recharge compared to north. This is consistent with the previous studies (i.e. Eccleston et al 1981).

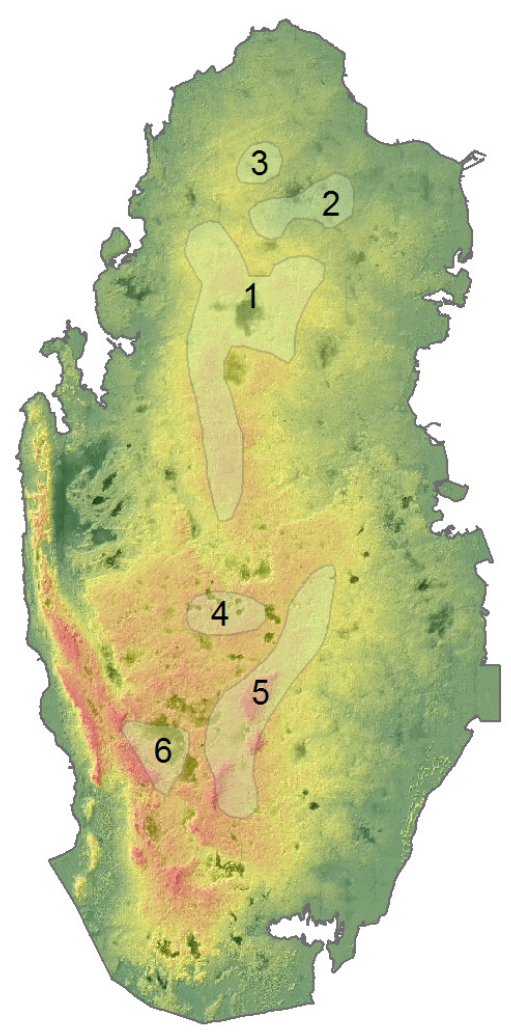

Figure 7. Major recharge areas.

\section{DISCUSSION AND CONCLUSIONS}

In this study a new approach was used to estimate natural groundwater recharge in Qatar. This approach is based on analysis of historical groundwater contour maps to identify groundwater recharge zones. These recharge zones occur at highest topography and where land depressions occur. With the help of GIS and using aquifer test data, the amount of groundwater flow from recharge zones was computed.

Rainfall recharge calculated using this method amounts to 25 million $\mathrm{m}^{3}$ per year, which is within the range of previous studies estimation. Groundwater movement in the shallow aquifer that receives rainfall recharge is more or less similar to topography. It is important to note that the main recharge occur in the northern part of the country where hydraulic conductivity is higher. 


\section{REFERENCES}

Alsharhan, A. S.; Rizk, Z.A.; Nairn, A.E.M.; Bakhit, D.W. and Alhajari, S.A. (2001) Hydrogeology of an arid region : the Arabian Gulf and adjoining areas. Elsevier.

Al-Yousef, Mariam (2003). Mineralogy, geochemistry and origin of quaternary sabkhas in the Qatar peninsula, Arabian Gulf; 437 pages. PhD Thesis, University of Southampton.

Boukhary, Mohammad; Hewaidy, Abdel Galil ; Luterbacher, Hanspeter; Bassiouni, Mohamed El-Amin; and Al-Hitmi, Hind. (2011) Foraminifera and ostracodes of Early Eocene Umm er Radhuma Formation, Dukhan Oil Field, Qatar. micropaleontology, vol. 57, no. 1, plates 1-6. Pp 37-60

Eccleston, B.L., Pike, J. G. and Harhash, I. (1981). The Water Resources of Qatar and Their Development.

Food and Agriculture Organisation of the United Nations (FAO) (2014). AQUASTAT global water information system. [http://www.fao.org/nr/water/aquastat/main/index.stm] last accessed October 2014

Kimrey, John (1985). Proposed artificial recharge studies in northern Qatar. United States Department of the Interior Geological Survey. Open file report 85-343.

Schlumberger Water Services (2009). Studying and developing the natural and artificial recharge of the groundwater in aquifer in the State of Qatar.

The World Bank (2014). [http://www.worldbank.org/] Last visited May 2015

United Nations (2013). Inventory of shared water resources in western Asia. /ESCWA/SDPD/2013/ Inventory. ISBN-13. 978-92-1-128361-7

Vecchioli, John (1976) Preliminary Evaluation of the Feasibility of Artificial Recharge in Northern Qatar. United States Geological Survey. Open File Report (76-540).

Yurtsever, Y.; Payne, B.R. (1978).Application of environmental isotopes to groundwater investigations in Qatar. International symposium on isotope hydrology; Neuherberg/Muenchen, Germany, F.R; 19 - 23 Jun 1978; AED-CONF--78-239-010; IAEA-SM--228/24 